\title{
Performance of $\mathrm{WO}_{3}$-Incorporated Carbon Electrodes for Ambient Mesoscopic Perovskite Solar Cells
}

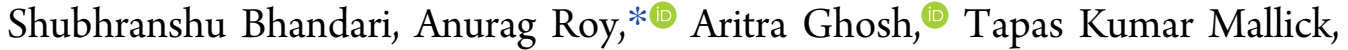 \\ and Senthilarasu Sundaram* \\ Environment and Sustainability Institute (ESI), Penryn Campus, University of Exeter, Cornwall TR10 9FE, U.K.

\section{Supporting Information}

\begin{abstract}
The stability of perovskite solar cells (PSC) is often compromised by the organic hole transport materials (HTMs). We report here the effect of $\mathrm{WO}_{3}$ as an inorganic HTM for carbon electrodes for improved stability in PSCs, which are made under ambient conditions. Sequential fabrication of the PSC was performed under ambient conditions with mesoporous $\mathrm{TiO}_{2} / \mathrm{Al}_{2} \mathrm{O}_{3} / \mathrm{CH}_{3} \mathrm{NH}_{3} \mathrm{PbI}_{3}$ layers, and, on the top of these layers, the $\mathrm{WO}_{3}$ nanoparticle-embedded carbon electrode was used. Different concentrations of $\mathrm{WO}_{3}$ nanoparticles as HTM incorporated in carbon counter electrodes were tested, which varied the stability of the cell under ambient conditions. The addition of $7.5 \% \mathrm{WO}_{3}$ (by volume) led to a maximum power conversion efficiency of $10.5 \%$, whereas the stability of the cells

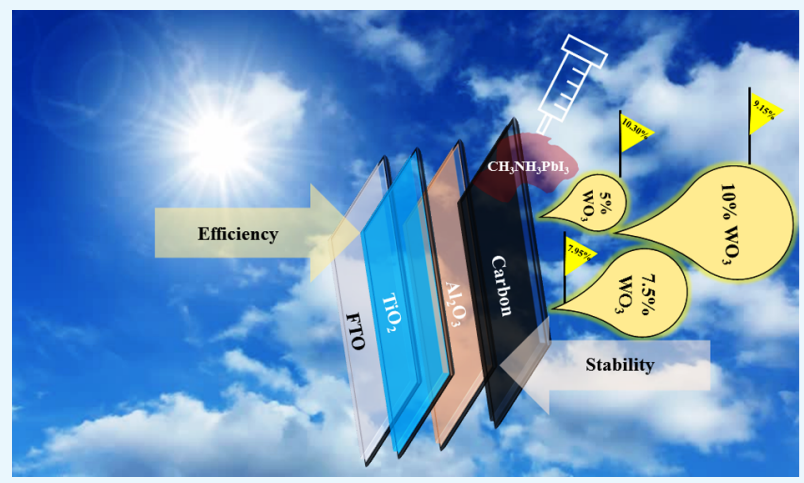
under ambient condition was $\sim 350 \mathrm{~h}$, maintaining $\sim 80 \%$ of the initial efficiency under light illumination. At the same time, the higher $\mathrm{WO}_{3}$ concentration exhibited an efficiency of $9.5 \%$, which was stable up to $\sim 500 \mathrm{~h}$ with a loss of only $\sim 15 \%$ of the initial efficiency under normal atmospheric conditions and light illumination. This work demonstrates an effective way to improve the stability of carbon-based perovskite solar cells without affecting the efficiency for future applications.
\end{abstract}

\section{INTRODUCTION}

Technology development with improved levels of sustainability can create opportunity for today's state of the art photovoltaic devices as well as develop existing materials to improve performance. Organic-inorganic hybrid solar cells with perovskite-type pigments have been much studied in recent years. The solar cells incorporating a $\mathrm{CH}_{3} \mathrm{NH}_{3} \mathrm{PbI}_{3}\left(\mathrm{MAPbI}_{3}\right)$ compound with a perovskite structure have shown high photoconversion efficiencies (PCEs). Perovskite solar cells (PSCs) have recently become one of such technology and an area of interest owing to their lower preparation cost and highconversion efficiency in the field of solar cell research. ${ }^{1-3}$ The investigation in the field of PSCs has increased in recent years, and a highest recorded efficiency of $25.2 \%$ was achieved in early 2019, which has been independently confirmed by the international authority and authenticating institution, National Renewable Energy Laboratory (NREL). ${ }^{4,5}$ Large-area PSCs with an active area $>1 \mathrm{~cm}^{2}$ exhibited a maximum photoconversion efficiency (PCE) of $20.5 \%$ and a certified PCE of $19.6 \%{ }^{6}$ Since the maximum theoretical PCE of the PSCs employing $\mathrm{MAPbI}_{3}$ is around $31 \%$, there is still great scope for development. ${ }^{7}$ In addition to the high PCE achieved with the halide perovskites, these materials are composed of only earthabundant elements and can be prepared by various low-cost methods. It is, therefore, highly anticipated that implantation of PSCs could be deployed on an industrial scale. The perovskite materials now focus on some challenging issues, for instance, the high PCE solar cells are still based on toxic $\mathrm{Pb}$ contamination and the halide salts tend to dissociate in the presence of moisture, which causes stability issue for long-term usage. $^{8}$ As per the toxicity concern of using $\mathrm{Pb}$, extensive research effort has been committed to the development of lead-free perovskites such as $\mathrm{CH}_{3} \mathrm{NH}_{3} \mathrm{SnI}_{3}, \mathrm{CH}\left(\mathrm{NH}_{2}\right)_{2} \mathrm{SnI}_{3}$, $\mathrm{CsSnI}_{3}, \mathrm{Cs}_{2} \mathrm{SnI}_{6}, \mathrm{BaZrS}_{3}, \mathrm{CaZrSe}_{3}, \mathrm{CaHfSe}_{3}$, etc. for photovoltaic applications. ${ }^{9,10}$ It has been observed that the oxide perovskites exhibit more water resistivity compared to the halide perovskite. Besides, it is facile to tune the band gap of the oxide perovskite to match the solar spectrum and, therefore, act as a photoanode candidate for dye-sensitized solar cells (DSSCs). Extensive research on DSSCs enlarged the development pathway of planar structured PSCs in the initial stages. ${ }^{11-13}$ The planar structure of PSCs became more prevalent when both the electron and hole transport properties have been simultaneously observed for the perovskite material. ${ }^{14-16}$ Highly efficient PSCs sometimes rapidly lose their efficiency due to the hygroscopic character of the materials used. ${ }^{17}$ Therefore, selection of materials and their fabrication process has limited the performance of PSCs. To overcome these issues, the mesoporous PSCs (m-PSCs) have come into account due to their simple fabrication process, high energy

Received: September 9, 2019

Accepted: November 19, 2019

Published: December 30, 2019 
conversion, and enhanced resistivity toward environmental factors. ${ }^{18,19}$ The mesoporous PSC includes carbon-based back contact, a suitable solution to substitute noble metals, due to its low cost, high conductivity, and eventually low-temperature processing and work function close to that of gold. ${ }^{20}$ However, it would be advantageous to do so to increase the flexibility and the overall transparency of the device.

To develop high-efficiency and stable devices as well as environmentally benign perovskites is critical, yet challenging aspects remain in PSC research. Moisture sensitivity of the organic constituents of the PSC device resulting in long-term stability issue for its commercialization. ${ }^{17,21}$ However, further involvements are required to enhance the commercial viability of PSC, which may be achieved through careful manipulation of the nanoscale structure and the implementation of novel processing techniques. To address the stability challenges, $\mathrm{Al}_{2} \mathrm{O}_{3}$ layer deposition, $\mathrm{Li}$-doping, and Cs-doping inclusion to perovskite layer have been introduced for their long-term implementation. $^{22,23}$ Previously, Grätzel et al. reported that employment of solid-state organic hole transport materials (HTM) boosted the reported efficiency of solid-state m-PSCs to $9.7 \% .{ }^{11}$ Similarly, Nazeeruddin et al. introduced a sandwichtype layer of mesoporous $\mathrm{TiO}_{2}$ and $\mathrm{MAPbI}_{3}$ as a light harvester with polymeric HTMs, which resulted in an efficiency of $12 \%$. ${ }^{24}$ Seok's group used $\mathrm{CH}_{3} \mathrm{NH}_{3} \mathrm{Pbl}_{3-x} \mathrm{Br}_{x}$-based mixed halide perovskites to further improve the efficiency to $\sim 12.3 \%$ and also to achieve better stability. ${ }^{25}$ On the other hand, Lee et al. reported a PSC composed of mesoporous $\mathrm{Al}_{2} \mathrm{O}_{3}$ instead of $\mathrm{TiO}_{2}$, demonstrating that $\mathrm{Al}_{2} \mathrm{O}_{3}$ merely acted as a scaffold layer without injection of photoexcited electrons resulting in faster electron diffusion through the perovskite layer. ${ }^{26}$ Gracini et al. reported 1 year stable PSCs using a two-dimensional/threedimensional (2D/3D) combined perovskite layer. ${ }^{27}$ To get high efficiency and stability, effort to modify the mesoporous layer has been also made for a PSC device. Similarly, $\mathrm{CuInS}_{2}$ quantum dot-modified $\mathrm{TiO}_{2}$ nanoarrays were introduced by Gao et al. for better stability of devices. ${ }^{28}$ Zhang et al. reported $\mathrm{SnO}_{2}$-based devices with $17.83 \%$ efficiency. ${ }^{29}$ However, to develop high-efficiency and stable devices as well as environmentally supported perovskites is still a crucial challenge and offers new and promising opportunities. ${ }^{30-32}$

Due to the ease of fabrication and higher efficiency, solar cells are often chosen as sources of electrical energy harvester, emerging markets such as self-powering systems and portable/ wearable electronics. ${ }^{33}$ Recently, Huan et al. reported an inexpensive photovoltaic-electrochemical cell system containing a low-cost perovskite photovoltaic minimodule, exhibiting $\sim 2.3 \%$ solar-to-hydrocarbon efficiency. ${ }^{34}$ Intensive work is continuing for commercialization of perovskite photovoltaic technology as well. ${ }^{35-37}$

In these ways, several attempts have been made to enhance the performance of PSCs. In spite of encouraging performance, the drawbacks of organic HTM allow the development of inorganic HTM-based PSCs using $\mathrm{Co}_{3} \mathrm{O}_{4},{ }^{38} \mathrm{CuSCN},{ }^{39}$ $\mathrm{NiO},{ }^{40,41} \mathrm{CuS},{ }^{42}$ and others. ${ }^{43}$ Devices based on inorganic HTMs demonstrated better stability compared to a spiroOMeTAD-based PSC in ambient condition. ${ }^{44,45}$ Overall, to address the shortcomings associated with regular PSCs, carbon-based mesoscopic PSCs with inorganic HTM have attracted serious attention. Very recently, our group reported efficient PSC with $\mathrm{WO}_{3}$ nanoparticle as HTM. ${ }^{46}$ Established electrochromic property of $\mathrm{WO}_{3}$ has been commercially inspected in electrochromic applications such as "smart windows" ${ }^{47,48}$ It can lead to an integrated photoelectrochromic device, instead of sequential conjoining of a solar cell followed by a full electrochromic device. Using $\mathrm{WO}_{3}$-based perovskite solar cells opens the possibility of further development in building-integrated photovoltaic (BIPV) application in terms of their low-energy, cost-effective, and novel architecture-based futuristic use.

Here, we report the performance of $\mathrm{MAPbI}_{3}$-based PSCs with a mesoporous $\mathrm{TiO}_{2} / \mathrm{Al}_{2} \mathrm{O}_{3} /$ carbon architecture where $\mathrm{WO}_{3}$ nanoparticle-based carbon back contact was employed. The method is based on a fully wet deposition process, which takes less time and utilizes a screen-printing method. The influence of the different amounts of $\mathrm{WO}_{3}$ is observed using 5, 7.5 , and $10 \% \mathrm{WO}_{3}$ (by volume) in the carbon paste and compared with a device without $\mathrm{WO}_{3}$ used as a reference, respectively. The purpose of this experiment was to develop stable PSC devices without using glovebox conditions and without any encapsulation. In our earlier reported paper, stability of the unsealed devices was very poor, $23 \%$ decay of initial PCE values within $100 \mathrm{~h}$. The PSC fabrication technique was adopted from our earlier report with a modification of different $\mathrm{WO}_{3}$ concentrations consisting of carbon layer deposition for back contact. ${ }^{46}$ A schematic description of the PSC fabrication processes is given (steps $\mathrm{a}-\mathrm{g}$ ) in Figure 1.

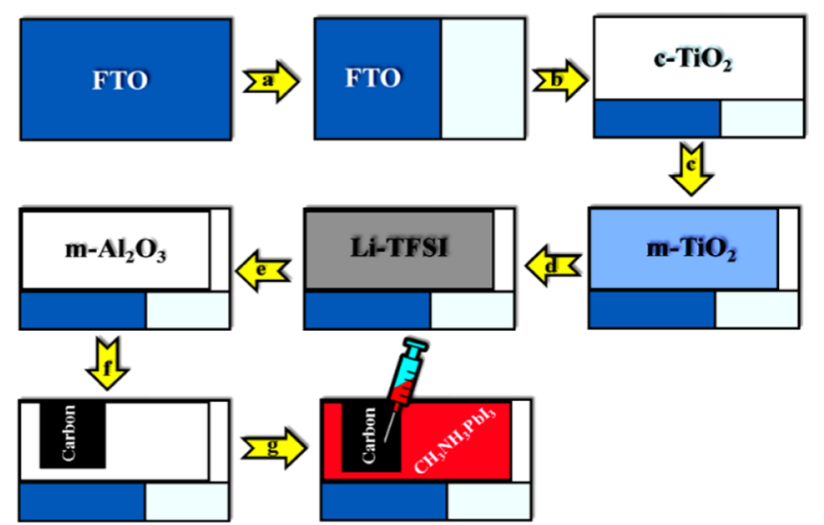

Figure 1. Stepwise fabrication process of the mesoporous perovskite solar cell. Step a: Etching of fluorine-doped tin oxide (FTO) glass; step b: compact $\mathrm{TiO}_{2}$ layer deposition; step c: mesoporous $\mathrm{TiO}_{2}$ layer formation; step d: lithium doping using lithium bis-(trifluoromethanesulfonyl) imide (Li-TFSI); step e: spin coating of mesoporous $\mathrm{Al}_{2} \mathrm{O}_{3}$ layer; step $\mathrm{f}$ : screen printing of the carbon electrode; step g: perovskite layer formation.

\section{RESULTS AND DISCUSSION}

The stepwise fabrication process with schematic structures is shown in Figure 1. Step a resembles etching of a FTO glass substrate. Step b and step c reflect the deposition of a compact $\mathrm{TiO}_{2}$ layer and mesoporous $\mathrm{TiO}_{2}$ layers, respectively. Lithium doping and mesoporous $\mathrm{Al}_{2} \mathrm{O}_{3}$ layer addition are shown in step $\mathrm{d}$ and step e, respectively. Screen printing of the $\mathrm{WO}_{3}$ nanoparticles incorporated the carbon layer is represented by step f. Finally, the drop casting and spin coating of the perovskite were carried out, as shown in step g. The homogenous mixture for different carbon pastes was prepared by using the ball-milling technique. The cross-sectional FESEM image (Figure 2a) of the device shows the appropriate orientation of the layers in the following sequence FTO/c$\mathrm{TiO}_{2} / \mathrm{m}-\mathrm{TiO}_{2} / \mathrm{m}-\mathrm{Al}_{2} \mathrm{O}_{3} /$ carbon from bottom to top. The 
(a)

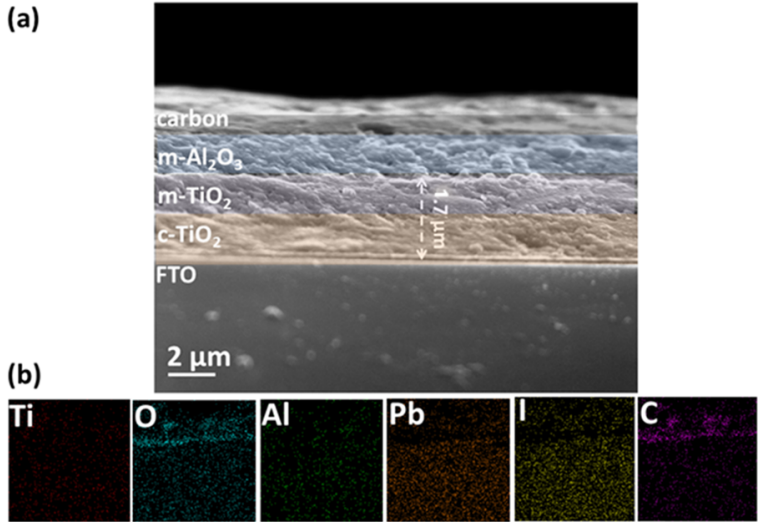

Figure 2. (a) Cross-sectional field emission scanning electron microscope (FESEM) image of the $\mathrm{TiO}_{2} / \mathrm{Al}_{2} \mathrm{O}_{3} /$ carbon device with $\mathrm{MAPbI}_{3}$ and (b) energy dispersive X-ray (EDX) elemental color mapping of $\mathrm{Ti}, \mathrm{O}, \mathrm{Al}, \mathrm{Pb}, \mathrm{I}$, and $\mathrm{C}$ of the device.

average thicknesses of mesoporous $\mathrm{TiO}_{2}$ and mesoporous $\mathrm{Al}_{2} \mathrm{O}_{3}$ layers are $\sim 700$ and $\sim 500 \mathrm{~nm}$, respectively.

Corresponding energy dispersive X-ray (EDX) mapping confirms the distribution of elements and successful deposition of different layers, as shown in Figure 2b. The distribution of lead and iodine also confirms that the perovskite $\left(\mathrm{MAPbI}_{3}\right)$ layer had spread through the carbon layer as well as the mesoporous layers. To confirm the existence of $\mathrm{WO}_{3}$, the EDX characterization was carried out and the EDX spectrum is given in Figure S1, supplementary information (ESI).

The XRD pattern of synthesized $\mathrm{CH}_{3} \mathrm{NH}_{3} \mathrm{PbI}_{3}$ thin films on the FTO glass substrate is shown in Figure 3. Except for the

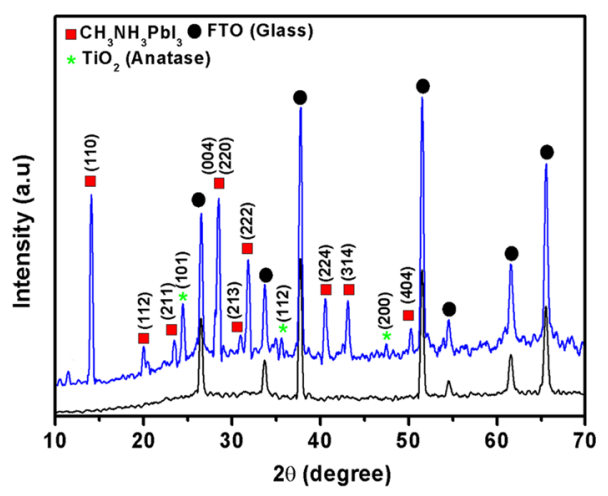

Figure 3. X-ray diffraction patterns of the $\mathrm{MAPbI}_{3} / \mathrm{Al}_{2} \mathrm{O}_{3} / \mathrm{TiO}_{2} / \mathrm{FTO}$ device (in blue) with major peaks for (110), (211), (220), and (213) planes are given in comparison to the blank FTO (in black).

signals of FTO glass and anatase $\mathrm{TiO}_{2}$ shown with black and green dots, respectively, all remaining signals are responsible for the $\mathrm{MAPbI}_{3}$ perovskite. The typical peaks at 14.10, 23.47, 28.42 , and $30.89^{\circ}$ correspond to the (110), (211), (220), and (213) planes of the tetragonal phase of $\mathrm{MAPbI}_{3}$. XRD study confirms the phase purity and crystalline features of $\mathrm{MAPbI}_{3}$, as reported previously. ${ }^{50,51}$

To evaluate the performance of the prepared m-PSCs made in ambient condition, the current vs voltage $(J-V)$ characteristic measurement was performed under simulated AM 1.5 $\left(100 \mathrm{~mW} / \mathrm{cm}^{2}\right)$. Figure $4 \mathrm{a}$ and Table 1 exhibit the photovoltaic parameters such as efficiency, short-circuit current density $\left(J_{\mathrm{SC}}\right)$, open-circuit voltage $\left(V_{\mathrm{OC}}\right)$, and fill factor $(\mathrm{FF})$ of the cells with an active area of $0.16 \mathrm{~cm}^{2}$. Photovoltaic performance of the devices was examined, and the maximum photoconversion efficiency (PCE) was found $\sim 10.5 \%$ having $J_{\text {SC, }} V_{\text {OC }}$, and FF of $21.2 \mathrm{~mA} / \mathrm{cm}^{2}, 854.4 \mathrm{mV}$, and 0.58 , respectively, for the device with $7.5 \% \mathrm{WO}_{3}$, whereas the highest achieved efficiencies for 5 and $10 \% \mathrm{WO}_{3}$ devices were $\sim 8.3$ and $\sim 9.4 \%$, respectively. The high $J_{\mathrm{SC}}$ values may have occurred due to the $\mathrm{Al}_{2} \mathrm{O}_{3}$ layer deposition, which acts as a spacer layer that retards the recombination between $\mathrm{TiO}_{2}$ and the carbon electrode.

IPCE resembles the external quantum efficiency of the DSSC device, which includes the effects of optical losses caused by transmission and reflection. The IPCE curve for $\mathrm{m}$ PSCs exhibited a broad peak over the range of 300-800 nm with a maximum value of $\sim 89 \%$ for the $7.5 \% \mathrm{WO}_{3}$-based device at a wavelength of $550 \mathrm{~nm}$ indicating high charge collection efficiency in cells, as shown in Figure $4 \mathrm{~b}$. Due to a narrow band gap of $\sim 1.55 \mathrm{eV}$, the $\mathrm{MAPbI}_{3}$ provides high extinction coefficient resulting in broad IPCE spectra from the visible range to a part of the near-infrared. Further, calculation of the integrated photocurrent density was evaluated from the overlap integral of the IPCE spectra as recorded in Figure $4 \mathrm{~b}$ with the AM 1.5 solar emission for different devices and values mentioned in Table S1 (ESI). The average integrated photocurrent densities of PSCs with different amounts of $\mathrm{WO}_{3}$ additive closely match with photocurrent densities obtained from the $J-V$ curve.

The nature of forward and reverse scanned $J-V$ plots gives impression of hysteresis. Significant hysteresis is observed for all of the different sets of devices, as shown in Figure 5a-c. Hysteresis is more pronounced for the devices with $7.5 \% \mathrm{WO}_{3}$, as can be seen from Figure $5 \mathrm{~b}$. Figure $5 \mathrm{~d}$ provides the power output of all of the PSC devices per unit cross-sectional area. The enhanced power density was observed for $\mathrm{WO}_{3}$-added devices compared to the device without $\mathrm{WO}_{3}$ treatment. Similar to the $J-V$ plot, the power density reaches its maximum values of $5.89 \mathrm{~mW} / \mathrm{cm}^{2}$ for $7.5 \% \mathrm{WO}_{3}$.

Figure S2 (ESI) provides the variance of $V_{\mathrm{OC}}, J_{\mathrm{SC}}$, fill factor, and PCE values for a batch of 10 devices from each set. The overall PCE values range from 10.1 to $10.5 \%$ in the case of the $7.5 \%$ of the $\mathrm{WO}_{3}$-added devices. Interestingly, the fill factor of devices with a lower amount of $\mathrm{WO}_{3}$ is higher than that of the others.

Further, the electrochemical impedance spectroscopy (EIS) measurements were carried out to understand the transport properties at different interfaces in the m-PSC assembly. The EIS spectra (Nyquist plot) with equivalent circuit diagram and corresponding Bode phase diagram of the concerned PSCs were recorded under dark at $0.7 \mathrm{~V}$ bias from 10 to $1 \mathrm{MHz}$, as shown in Figure $6 a, b$, respectively. In the circuit diagram (inset of Figure $6 \mathrm{a}), R_{\mathrm{S}}$ represents the series resistance, which include resistance of FTO and carbon counter electrode. $R_{\text {rec }}$ is the charge-transfer resistance at the perovskite/carbon interface and $R_{\mathrm{CT}}$ is the charge-transfer resistance at the $\mathrm{TiO}_{2} / \mathrm{MAPbI}_{3}$ interface. It can be interpreted from Figure 6a that the large parabola in the high-frequency region indicates higher transportation and exchange resistance from the perovskite to the carbon counter electrode, so it will affect the fill factor as reflected from $J-V$ characterization. On the other hand, the smaller parabola reflects the recombination resistance between $\mathrm{TiO}_{2}$ and the perovskite interface. The large $R_{\mathrm{CT}}$ value implies a slow charge recombination process or low charge recombination rate. This low recombination rate is responsible for high values of $J_{\mathrm{SC}}$ and $V_{\mathrm{OC}}$, which is reflected in the $J-V$ 

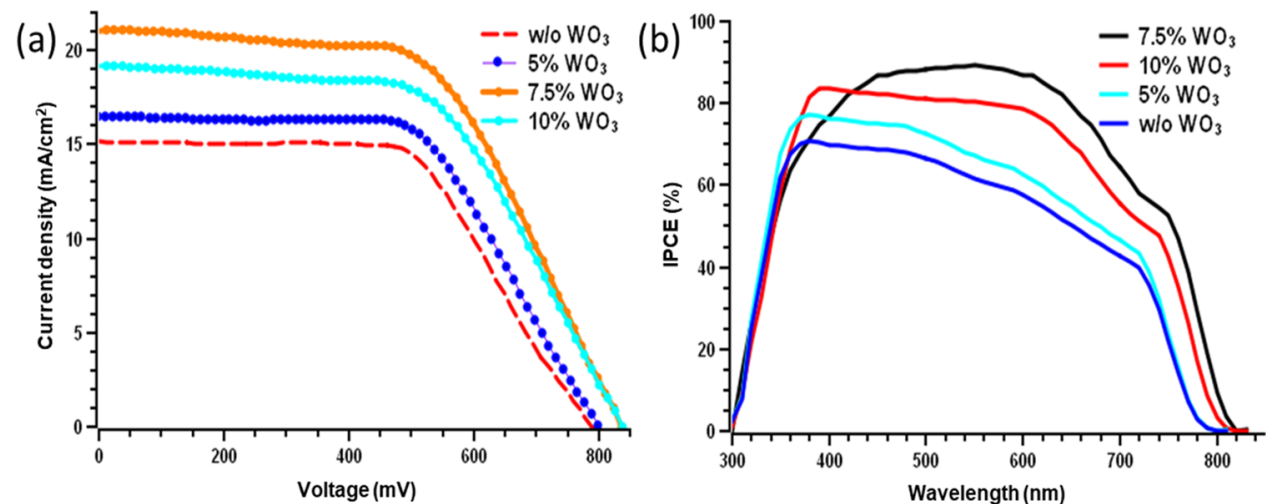

Figure 4. (a) Current-voltage $(J-V)$ curves and (b) incident photon to current efficiency (IPCE) spectra for different m-PSCs containing 5, 7.5, $10 \%$ of $\mathrm{WO}_{3}$ compared with and without $(\mathrm{w} / \mathrm{o}) \mathrm{WO}_{3}$-based devices, respectively.

Table 1. Photovoltaic Parameters of Ambient Mesoporous Perovskite Solar Cells under 1 SUN AM1.5 G, with an Active Area of $0.16 \mathrm{~cm}^{2}$

\begin{tabular}{lccrcc}
\multicolumn{1}{c}{ sample } & $V_{\mathrm{OC}}(\mathrm{mV})$ & $J_{\mathrm{SC}}\left(\mathrm{mA} / \mathrm{cm}^{2}\right)$ & fill factor $(\mathrm{FF})$ & \multicolumn{1}{c}{ PCE $(\%)$} & power output $\left(\mathrm{mW} / \mathrm{cm}^{2}\right)$ \\
without $\mathrm{WO}_{3}$ & $788.8 \pm 15$ & $15.16 \pm 0.1$ & $0.62 \pm 0.01$ & $7.40 \pm 0.3$ & 4.54 \\
$5 \% \mathrm{WO}_{3}$ & $801.3 \pm 20$ & $16.4 \pm 0.15$ & $0.605 \pm 0.01$ & $7.95 \pm 0.4$ & 4.86 \\
$7.5 \% \mathrm{WO}_{3}$ & $842.3 \pm 20$ & $21.1 \pm 0.2$ & $0.58 \pm 0.01$ & $10.30 \pm 0.2$ & 5.89 \\
$10 \% \mathrm{WO}_{3}$ & $840.4 \pm 15$ & $19.3 \pm 0.15$ & $0.56 \pm 0.01$ & $9.15 \pm 0.3$ & 5.22 \\
\hline
\end{tabular}
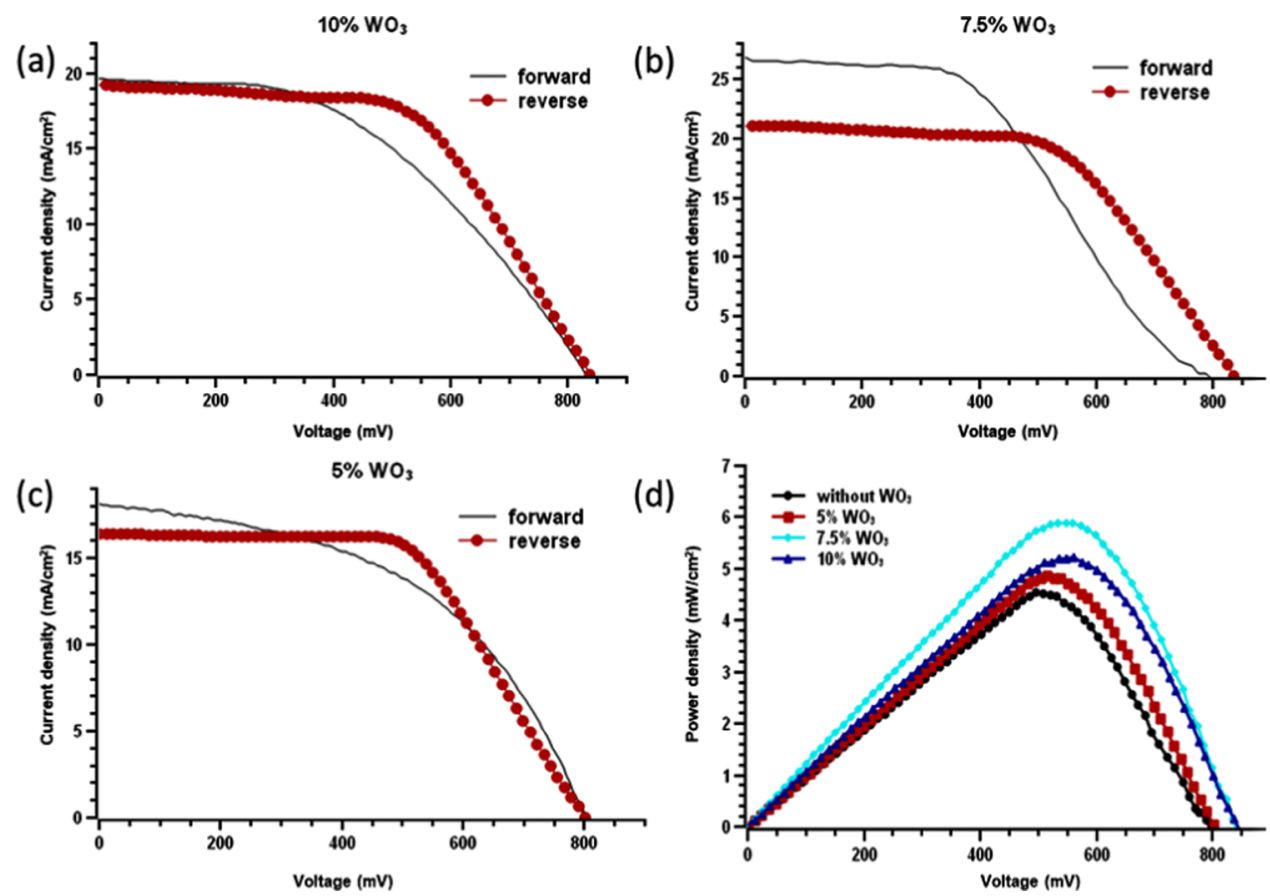

Figure 5. $J-V$ characteristic plot showing the forward and reverse scans with an active area of $0.16 \mathrm{~cm}^{2}$ under $1 \mathrm{sun}\left(100 \mathrm{~mW} / \mathrm{cm}^{2}\right)$ light illumination for devices with (a) $10 \%$, (b) $7.5 \%$, and (c) $5 \% \mathrm{WO}_{3}$ and (d) corresponding power density vs voltage plot.

curve. Devices with higher $R_{\mathrm{S}}$ value should have lower efficiency, which can be observed from Table S2 (ESI). Long-term stability is the most critical challenge for PSCs under ambient conditions without any encapsulation. The stability of the PSC is environment dependent, mostly affected by the humidity, light conditions, and climatic conditions. ${ }^{52}$

The PSCs were kept at ambient conditions, to understand the degradation pattern of the solar cell. The prepared PSCs were characterized under illumination for $\sim 500 \mathrm{~h}$, as shown in Figure $7 \mathrm{a}-\mathrm{c}$. It was observed that the amount of $\mathrm{WO}_{3}$ controls the stability of the devices. Figure $7 \mathrm{a}, \mathrm{b}$ indicates a steady decrease in $J_{\mathrm{SC}}$ and $V_{\mathrm{OC}}$ with time, respectively. The devices with a higher amount of $\mathrm{WO}_{3}$ maintain their efficiency for a longer time. The device containing $7.5 \%$ of $\mathrm{WO}_{3}$ maintained its stability with a loss of $20 \%$ efficiency up to $\sim 350 \mathrm{~h}$. Significantly, stability of $\sim 500 \mathrm{~h}$ is observed for the device with $10 \%$ of $\mathrm{WO}_{3}$ and it maintains the PCE of $\sim 85 \%$ of the initial value (Figure $7 \mathrm{c}$ ). The presence of inorganic HTM may stabilize the device in these purposes. This result indicates that higher concentration of $\mathrm{WO}_{3}$ affects the power conversion efficiency, but at the same time it increases the stability of the devices. The use of $\mathrm{WO}_{3} /$ carbon electrode reduces the 
(a)

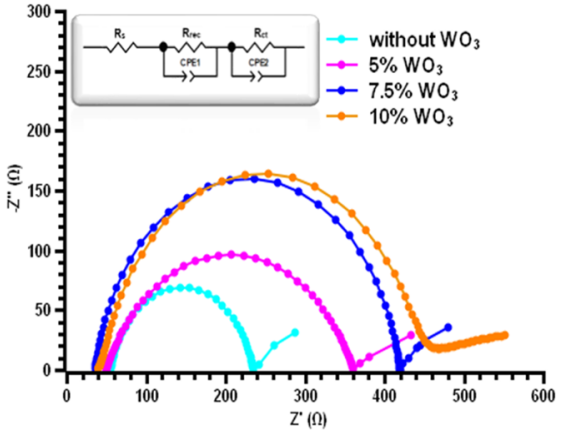

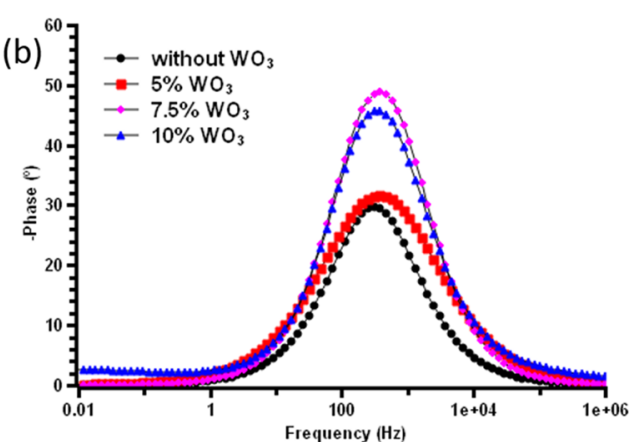

Figure 6. (a) EIS characteristics (Nyquist plots) with the fitted circuit diagram and (b) corresponding Bode phase plot of different PSCs.

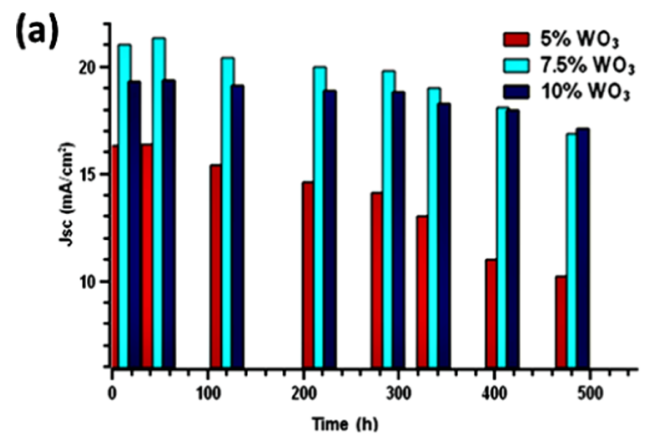

(c)

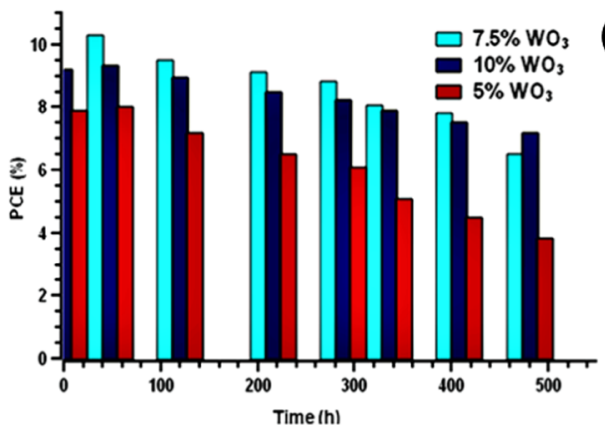

(b)

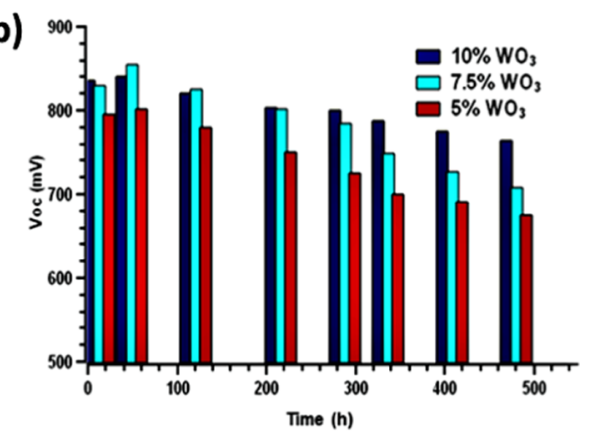

(d)

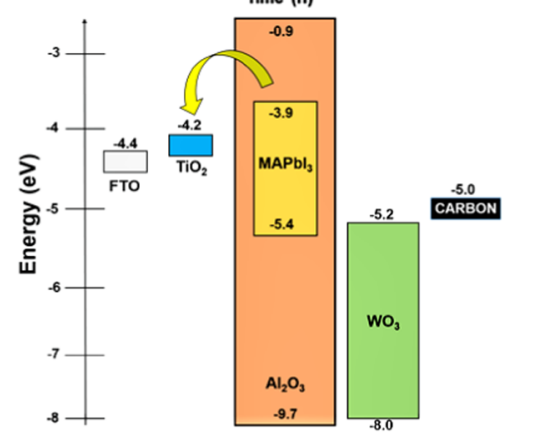

Figure 7. Photovoltaic characterization of 5, 7.5, and $10 \% \mathrm{WO}_{3}$-contained devices in terms of their (a) current density $\left(J_{\mathrm{SC}}\right)$, (b) open circuit voltage $\left(V_{\mathrm{OC}}\right),(\mathrm{c})$ PCE monitored up to $500 \mathrm{~h}$, respectively and $(\mathrm{d})$ schematic diagram of energy band position of the $\mathrm{WO}_{3}$-added perovskite solar cell.

porosity of the layer due to the presence of small sized $\mathrm{WO}_{3}$ nanoparticles. The small porosity of the electrode layer could help to prevent the permeability of moisture/oxygen through the counter electrode. This may be the reason behind the greater stability of devices with a higher amount of $\mathrm{WO}_{3}$ nanoparticle in the electrode material. A simple schematic energy band diagram of the carbon-based mesoscopic PSCs with $\mathrm{WO}_{3}$ nanoparticles additive is shown in Figure $7 \mathrm{~d}$. According to the energy-level positions of different components, the excited electron is transferred from the conduction band of the $\mathrm{MAPbI}_{3}$, perovskite layer $(-3.9 \mathrm{eV})$ to that of the $\mathrm{TiO}_{2}$ layer $(-4.0 \mathrm{eV})$ followed by the hole extraction from the perovskite layer $(-5.4 \mathrm{eV})$ to the carbon layer $(-5.0 \mathrm{eV})$ via $\mathrm{WO}_{3}(-5.3 \mathrm{eV}) . \mathrm{Al}_{2} \mathrm{O}_{3}$ layer served as a spacer and retards the electron-hole recombination in the PSCs. The additive $\mathrm{WO}_{3}$ inside the carbon film can work as HTM to promote the holeextraction in the perovskite/carbon interface due to its appropriate position of the conduction band. ${ }^{46,53,54}$ This is further facilitated by energy-level matching, which helps a notable improvement in the hole extraction, recombination resistance compared to without $\mathrm{WO}_{3}$-based device.
It is proposed that incorporating $\mathrm{WO}_{3}$ in $\mathrm{Pt} \mathrm{CE}$ favorably occupies the gap states near the Fermi level and maintains high work function, which accelerates the charge transportation and enhances charge extraction of $\mathrm{Pt}$ in PSC. Treatment with $\mathrm{WO}_{3}$ may also take part similarly in modifying the electronic structure of carbon and can be explored as a hole-transporting layer for PSC. The electron hopping conduction mechanism is the most probable reason behind the high electrical conductivity of the annealed $\mathrm{WO}_{3}$ at $500{ }^{\circ} \mathrm{C} .{ }^{55}$ The presence of oxygen vacancies in substoichiometric $\mathrm{WO}_{3}$ creates various defect states of $\mathrm{WO}_{3}$, such as $\mathrm{W}^{4+}$ or $\mathrm{W}^{5+}$ and $\mathrm{W}^{6+}$, located within the band gap, respectively. These may promote charge transfer and enhance the electrical conductivity in the mixed valence states of $\mathrm{W}^{4+}, \mathrm{W}^{5+}$, and $\mathrm{W}^{6+}$ accordingly. ${ }^{56,57}$ Also, the conductivity measurement data mentioned in Table S3 (ESI) clarify the performance of different devices. Besides, optimum amount of $\mathrm{WO}_{3}$ in the hybrid carbon paste plays a vital role in modifying the carbon counter electrode. Less amount of $\mathrm{WO}_{3}$ incorporation may result in insufficient work function of $\mathrm{WO}_{3}$ well, whereas an excessive amount may decrease the conductivity of the carbon and also effect transparency of the device. Further, this experimentation is comparable to 
Table 2. Stability Comparisons of Carbon-Based Mesoscopic Perovskite Solar Cells from Previous Reports Based on $\mathrm{MAPbI}_{3}$

\begin{tabular}{|c|c|c|c|c|}
\hline device structure & $\begin{array}{l}\text { average } \\
\text { PCE }(\%)\end{array}$ & stability of unsealed device & $\begin{array}{l}\text { active area } \\
\left(\mathrm{cm}^{2}\right)\end{array}$ & refs \\
\hline $\mathrm{FTO} / \mathrm{c}-\mathrm{TiO}_{2} / \mathrm{m}-\mathrm{TiO}_{2} / \mathrm{m}-\mathrm{ZrO}_{2} / \mathrm{Co}_{3} \mathrm{O}_{4} /$ carbon $/ \mathrm{MAPbI}_{3}$ & 11.7 & $\sim 2500 \mathrm{~h}$ in ambient condition in the presence of light & 0.8 & 38 \\
\hline $\mathrm{FTO} / \mathrm{m}-\mathrm{TiO}_{2} / \mathrm{m}-\mathrm{ZrO}_{2} / \mathrm{NiO} /$ carbon $/ \mathrm{MAPbI}_{3}$ & 13.7 & $\begin{array}{l}\text { PCE decreased to } 80 \% \text { of initial after } \sim 150 \mathrm{~h} \text { in the presence } \\
\text { of light }\end{array}$ & & 40 \\
\hline $\mathrm{FTO} / \mathrm{c}-\mathrm{TiO}_{2} / \mathrm{m}-\mathrm{TiO}_{2} / \mathrm{CH}_{3} \mathrm{NH}_{3} \mathrm{PbI}_{3} / \mathrm{C}-\mathrm{CuS}$ & 10.22 & $\begin{array}{l}\text { over } 600 \mathrm{~h} \text { in ambient condition with } 30-50 \% \text { humidity in } \\
\text { dark }\end{array}$ & & 42 \\
\hline $\mathrm{FTO} / \mathrm{c}-\mathrm{TiO}_{2} / \mathrm{m}-\mathrm{TiO}_{2} / \mathrm{m}-\mathrm{ZrO}_{2} /$ carbon $/ \mathrm{MAPbI}_{3}$ & 6.5 & $\sim 850 \mathrm{~h}$ in dry air condition at room temperature in dark & 0.125 & 58 \\
\hline $\mathrm{FTO} / \mathrm{c}-\mathrm{TiO}_{2} / \mathrm{m}-\mathrm{TiO}_{2} / \mathrm{m}-\mathrm{Al}_{2} \mathrm{O}_{3} /$ carbon $/ \mathrm{MAPbI}_{3}$ & 12.3 & $\begin{array}{l}\text { PCE decreased to } 1 \% \text { of initial after } \sim 480 \mathrm{~h} \text { under light at } \\
\text { room temperature }\end{array}$ & 0.09 & 59 \\
\hline $\mathrm{FTO} / \mathrm{c}-\mathrm{TiO}_{2} / \mathrm{m}-\mathrm{TiO}_{2} / \mathrm{m}-\mathrm{Al}_{2} \mathrm{O}_{3} / \mathrm{SWCNT}-\mathrm{NiO} / \mathrm{MAPbI}_{3}$ & 12.7 & $\sim 300 \mathrm{~h}$ in ambient condition & & 60 \\
\hline $\mathrm{FTO} / \mathrm{c}-\mathrm{TiO}_{2} / \mathrm{m}-\mathrm{TiO}_{2} / \mathrm{m}-\mathrm{Al}_{2} \mathrm{O}_{3} /$ carbon- $\mathrm{WO}_{3} / \mathrm{MAPbI}_{3}$ & 10.3 & $\begin{array}{l}85 \% \text { of initial PCE retains after } \sim 500 \mathrm{~h} \text { in ambient condition in } \\
\text { the presence of light }\end{array}$ & 0.16 & $\begin{array}{l}\text { this } \\
\text { work }\end{array}$ \\
\hline
\end{tabular}

those of other previous works related to inorganic HTM for carbon-based perovskite solar cells in the context of stability, as given in Table 2. Most of these devices have much less stability under light illumination except for the device with $\mathrm{Co}_{3} \mathrm{O}_{4}$. In our case, under light illumination devices with $10 \% \mathrm{WO}_{3}$ are fairly stable $(\sim 500 \mathrm{~h})$ without any substantial loss of efficiency.

\section{CONCLUSIONS}

In conclusion, we have demonstrated here the fully printable mesoporous perovskite solar cells with nanoparticles incorporated in the carbon back contact top electrode fabricated under ambient condition. These devices show interesting stability depending on the amount of $\mathrm{WO}_{3}(5,7.5$, and $10 \%$ by volume) in the carbon electrode. The efficiency increase was observed for the devices with nanoparticles in comparison to those without. The highest efficiency was obtained with the $7.5 \% \mathrm{WO}_{3}$ device, but the stability of devices with $10 \% \mathrm{WO}_{3}$ is more pronounced. The results suggest that depending on the amount of efficient additives, the device performance can be influenced remarkably. The obtained maximum efficiency was lower than the values reported for other PSCs; however, with all factors taken into account, the proposed option might emerge as be much more realistic and, thus, more promising. Further, this work demonstrates that the concentration variation of $\mathrm{WO}_{3}$ can improve the stability significantly for uncapped devices in open air conditions under light. This constitutes an important step toward the efficiency improvement of the devices for futuristic photoelectrochromic or selfpowered switchable glazing for low-energy adaptive façade integration.

\section{EXPERIMENTAL SECTION}

Device Fabrication. In details, the first step (step a) resembles etching of the fluorine-doped tin oxide (FTO) glass substrate. $\mathrm{Next}, \mathrm{TiO}_{2}$ compact layer was spin-coated at 2000 rpm for $30 \mathrm{~s}$ on the etched clean FTO transparent glass by using $0.15 \mathrm{M}$ titanium di-isopropoxide bis-(acetylacetonate) $\mathrm{Ti}(\mathrm{acac}){ }_{2} \mathrm{O}^{\mathrm{i}} \mathrm{Pr}_{2}$ (75 wt \% in isopropanol, Sigma-Aldrich) (99.9\%, Sigma-Aldrich) solution in 2-propanol, followed by drying at $115^{\circ} \mathrm{C}$ for $5 \mathrm{~min}$. This step is repeated for one more time, and finally the coated samples were then placed on a hot plate at a temperature of $415 \pm 10{ }^{\circ} \mathrm{C}$ for $30 \mathrm{~min}$ followed by cooling to room temperature (step b). The mesoporous $\mathrm{TiO}_{2}$ layer was deposited by spin coating at $2500 \mathrm{rpm}$ for $30 \mathrm{~s}$ using diluted $\mathrm{TiO}_{2}$ paste (18NRT from Great Cell Solar Company; $\mathrm{w} / \mathrm{w}=1: 3.5$ in ethanol) and heated at $500{ }^{\circ} \mathrm{C}$ for $60 \mathrm{~min}$ (step c). After cooling down to room temperature, lithium doping was carried out via spin coating $(3000 \mathrm{rpm}, 15 \mathrm{~s})$ of $0.1 \mathrm{M}$ lithium bis-(trifluoromethanesulfonyl) imide (Li-TFSI) solution in acetonitrile followed by annealing at $415 \pm 15{ }^{\circ} \mathrm{C}$ for $30 \mathrm{~min}$ (step d). Then, the $\mathrm{Al}_{2} \mathrm{O}_{3}$ mesoporous layer was spincoated with diluted $\mathrm{Al}_{2} \mathrm{O}_{3}$ paste (Sigma-Aldrich; $\mathrm{v} / \mathrm{v}=1: 2$ in isopropanol) at $2000 \mathrm{rpm}$ for $30 \mathrm{~s}$ and heated at $150{ }^{\circ} \mathrm{C}$ for 30 min (step e). To prepare the carbon paste for back contact, 1.2 $\mathrm{g}$ of graphite powder (Sigma-Aldrich) was mixed with $0.2 \mathrm{~g}$ of carbon black powder (Alfa Aesar) in $4.0 \mathrm{~mL}$ of $\alpha$-terpineol (Sigma-Aldrich). Then, $0.1 \mathrm{~g}$ of $\mathrm{ZrO}_{2}$ powder (Sigma-Aldrich), $1.5 \mathrm{~g}$ of ethyl cellulose (15 wt \% in ethanol) (Sigma-Aldrich), and three different amounts $(5,7.5$, and $10 \%$ by volume) of $\mathrm{WO}_{3-x}$ nanoparticle ink (2.5 wt \% in isopropanol, SigmaAldrich) were added to the above paste, followed by ball milling overnight. Thus, the prepared carbon paste was screenprinted above the mesoporous $\mathrm{Al}_{2} \mathrm{O}_{3}$ layer to obtain a mesoscopic carbon layer, which was sintered at $450{ }^{\circ} \mathrm{C}$ for $30 \mathrm{~min}$ (Step $\mathrm{f}$ ). The $\mathrm{MAPbI}_{3}$ perovskite solution was prepared via the ion-exchange method. In short, $0.198 \mathrm{~g}$ of $\mathrm{CH}_{3} \mathrm{NH}_{3} \mathrm{I}$ (Sigma-Aldrich) and $0.573 \mathrm{~g}$ of $\mathrm{PbI}_{2}$ (Sigma-Aldrich) were dissolved in $1 \mathrm{~mL}$ of $\gamma$-butyrolactone (Sigma-Aldrich) and then stirred at $60{ }^{\circ} \mathrm{C}$ overnight. ${ }^{41}$ After cooling down to room temperature, the perovskite precursor solution with an appropriate amount was infiltrated by drop casting via the top of the carbon counter electrode and further spin coating at $1000 \mathrm{rpm}$ for $15 \mathrm{~s}$. At last, drying was done at $50{ }^{\circ} \mathrm{C}$ for $1 \mathrm{~h}$ (Step g). Finally, the PSC was employed for further characterization and measurements. Note: All of the data represented here are the average measurement of five individual fabricated $\mathrm{m}$-PSC devices for each case. Their corresponding photovoltaic performance was monitored since last 6 months with negligible hysteresis effect and high reliability and repeatability at ambient condition. Every individual m-PCSs were measured in every $24 \mathrm{~h}$ up to $500 \mathrm{~h}$ to check their photovoltaic performance and stability. The cells were fabricated and stored at ambient condition for all of the cases. Box and whisker plot of efficiency measurements indicated the error range recorded during the period of device measurement (Figure S2, ESI).

Characterization. X-ray diffraction (XRD) analyses of the fabricated PSC films were carried out on a X'pert pro MPD XRD of PANalytical with $\mathrm{Cu} K \alpha$ radiation $(\lambda=1.5406 \AA$ ). The cross-sectional thickness measurement and elemental mapping of the PSC were recorded on a scanning electron microscope (SEM), (LEO 430i, Carl Zeiss). Further, testing of the PSC was executed under $1000 \mathrm{~W} / \mathrm{m}^{2}$ of light from a Wacom AAA continuous solar simulator (model: WXS-210S-20, AM $1.5 \mathrm{G}$ ). The $I-V$ characteristic of the devices was recorded using an EKO MP-160 I-V Tracer. EIS measurements were carried out 
with an AUTOLAB frequency analyzer setup equipped with an AUTOLAB PGSTAT 10 and a Frequency Response Analyzer (FRA) Module. The measurements were performed under the same solar simulator condition with the frequency range from 0.1 to $100 \mathrm{kHz}$. All of the devices were measured at the $0.70 \mathrm{~V}$ open-circuit voltage of the devices. The experimental data were fitted with the Z-view software (version 3.4d, Scribner Associates, Inc.) using appropriate equivalent circuits. Incident photon to current efficiency (IPCE) was carried out on a BENTHAM PVE300 Photovoltaic EQE (IPCE) and IQE solution under 350-750 $\mathrm{nm}$ wavelength using a tungsten halogen lamp source. ${ }^{46}$ The conductivity measurements were performed using the Ossila (UK) Four-Point Probe Instrument. All of the data presented are an average of measurements taken on three different devices.

\section{ASSOCIATED CONTENT}

\section{S Supporting Information}

The Supporting Information is available free of charge at https://pubs.acs.org/doi/10.1021/acsomega.9b02934.

SEM cross-sectional images of PSCs; box and whisker plot of the photovoltaic performance of the PSC devices; table of integrated current density and EQE obtained from IPCE measurement; table of EIS spectra fitting data; table of resistance and conductivity measurements (PDF)

\section{AUTHOR INFORMATION}

\section{Corresponding Authors}

*E-mail: A.Roy30@exeter.ac.uk, ar.chem30@gmail.com. Tel: 01326-259486 (A.R.).

*E-mail: S.Sundaram@exeter.ac.uk. (S.S.).

\section{ORCID}

Anurag Roy: 0000-0002-2097-9442

Aritra Ghosh: 0000-0001-9409-7592

Notes

The authors declare no competing financial interest.

\section{ACKNOWLEDGMENTS}

S.B would like to acknowledge the College of Engineering, Mathematics, and Physical Sciences, University of Exeter for the PhD fellowship. This work has been conducted as part of the research project "Joint UK-India Clean Energy Centre (JUICE)”, which is funded by the RCUK's Energy Programme (contract no: EP/P003605/1). The project's funders were not directly involved in writing of this article. In support of open access research, all underlying article materials (data, experimental details) can be accessed upon request via email to the corresponding author.

\section{REFERENCES}

(1) Park, N.-G. Organometal perovskite light absorbers toward a $20 \%$ efficiency low-cost solid-state mesoscopic solar cell. J. Phys. Chem. Lett. 2013, 4, 2423-2429.

(2) Xing, G.; Mathews, N.; Sun, S.; Lim, S. S.; Lam, Y. M.; Grätzel, M.; Mhaisalkar, S.; Sum, T. C. Long-range balanced electron- and hole-transport lengths in organic-inorganic $\mathrm{CH}_{3} \mathrm{NH}_{3} \mathrm{PbI}_{3}$. Science 2013, 342, 344-347.

(3) Grätzel, M. The light and shade of perovskite solar cells. Nat. Mater. 2014, 13, 838.
(4) Green, M. A.; Hishikawa, Y.; Dunlop, E. D.; Levi, D. H.; HohlEbinger, J.; Ho-Baillie, A. W. Y. Solar cell efficiency tables (version 52). Prog. Photovoltaics 2018, 26, 427-436.

(5) Best Research-Cell Efficiency Chart; National Renewable Energy Laboratory: USA. https://www.nrel.gov/pv/cell-efficiency.html.

(6) Li, X.; Bi, D.; Yi, C.; De'coppet, J.-D.; Luo, J.; Zakeeruddin, S. M.; Hagfeldt, A.; Grätzel, M. A Vacuum flash-assisted solution process for high-efficiency large-area perovskite solar cells. Science 2016, 353, $58-62$.

(7) Sha, W. E. I.; Ren, X.; Chen, L.; Choy, W. C. H. The efficiency limit of $\mathrm{CH}_{3} \mathrm{NH}_{3} \mathrm{PbI}_{3}$ perovskite solar cells. Appl. Phys. Lett. 2015, 106, No. 221104.

(8) Fu, H. Review of lead-free halide perovskites as light-absorbers for photovoltaic applications: from materials to solar cells. Sol. Energy Mater. Sol. Cells 2019, 193, 107-132.

(9) Konstantakou, M.; Stergiopoulos, T. A critical review on tin halide perovskite solar cells. J. Mater. Chem. A 2017, 5, 11518-11549.

(10) Sun, Y.-Y.; Agiorgousis, M.-L.; Zhang, P.; Zhang, S. Chalcogenide perovskites for photovoltaics. Nano Lett. 2015, 15, $581-585$.

(11) Kim, H.-S.; Lee, C.-R.; Im, J.-H.; Lee, K.-B.; Moehl, T.; Marchioro, A.; Moon, S.-J.; Humphry-Baker, R.; Yum, J.-H.; Moser, J. E.; Grätzel, M.; Park, N.-G. Lead iodide perovskite sensitized all-solidstate submicron thin film mesoscopic solar cell with efficiency exceeding 9\%. Sci. Rep. 2012, 2, No. 591.

(12) Burschka, J.; Pellet, N.; Moon, S.-J.; Humphry-Baker, R.; Gao, P.; Nazeeruddin, M. K.; Grätzel, M. Sequential deposition as a route to high-performance perovskite-sensitized solar cells. Nature 2013, 499, 316.

(13) Upadhyaya, H. M.; Senthilarasu, S.; Hsu, M.-H.; Kumar, D. K. Recent progress and the status of dye-sensitised solar cell (dssc) technology with state-of-the-art conversion efficiencies. Sol. Energy Mater. Sol. Cells 2013, 119, 291-295.

(14) Christians, J. A.; Fung, R. C. M.; Kamat, P. V. An inorganic hole conductor for organo-lead halide perovskite solar cells. improved hole conductivity with copper iodide. J. Am. Chem. Soc. 2014, 136, 758764.

(15) Zhou, H.; Chen, Q.; Li, G.; Luo, S.; Song, T.-b.; Duan, H.-S.; Hong, Z.; You, J.; Liu, Y.; Yang, Y. Interface engineering of highly efficient perovskite solar cells. Science 2014, 345, 542-546.

(16) McMeekin, D. P.; Sadoughi, G.; Rehman, W.; Eperon, G. E.; Saliba, M.; Hörantner, M. T.; Haghighirad, A.; Sakai, N.; Korte, L.; Rech, B.; Johnston, M. B.; Herz, L. M.; Snaith, H. J. A mixed-cation lead mixed-halide perovskite absorber for tandem solar cells. Science 2016, 351, 151-155.

(17) Wang, R.; Mujahid, M.; Duan, Y.; Wang, Z.-K.; Xue, J.; Yang, Y. A review of perovskites solar cell stability. Adv. Funct. Mater. 2019, 29, No. 1808843.

(18) Duan, M.; Hu, Y.; Mei, A.; Rong, Y.; Han, H. Printable carbonbased hole-conductor-free mesoscopic perovskite solar cells: from lab to market. Mater. Today Energy 2018, 7, 221-231.

(19) Abate, A.; Correa-Baena, J.-P.; Saliba, M.; Su'ait, M. S.; Bella, F. Perovskite solar cells: from the laboratory to the assembly line. Chem. - Eur. J. 2018, 24, 3083-3100.

(20) Chen, H.; Yang, S. Carbon-based perovskite solar cells without hole transport materials: the front runner to the market? Adv. Mater. 2017, 29, No. 1603994.

(21) Kojima, A.; Teshima, K.; Shirai, Y.; Miyasaka, T. Organometal halide perovskites as visible-light sensitizers for photovoltaic cells. J. Am. Chem. Soc. 2009, 131, 6050-6051.

(22) Maniarasu, S.; Manjunath, V.; Ramasamy, E.; Veerappan, G. Chapter 9 - Hole conductor-free perovskite solar cells. In Perovskite Photovoltaics; 2nd ed.; Thomas, S.; Thankappan, A., Eds.; Academic Press, 2018; pp. 289-321.

(23) Bella, F.; Renzi, P.; Cavallo, C.; Gerbaldi, C. Caesium for perovskite solar cells: an overview. Chem. - Eur. J. 2018, 24, 1218312205.

(24) Heo, J. H.; Im, S. H.; Noh, J. H.; Mandal, T. N.; Lim, C.-S.; Chang, J. A.; Lee, Y. H.; Kim, H.-J.; Sarkar, A.; Nazeeruddin, M. K.; 
Grätzel, M.; Seok, S. I. Efficient inorganic-organic hybrid heterojunction solar cells containing perovskite compound and polymeric hole conductors. Nat. Photonics 2013, 7, 486.

(25) Noh, J. H.; Im, S. H.; Heo, J. H.; Mandal, T. N.; Seok, S. I. Chemical management for colorful, efficient, and stable inorganicorganic hybrid nanostructured solar cells. Nano Lett. 2013, 13, 17641769.

(26) Lee, M. M.; Teuscher, J.; Miyasaka, T.; Murakami, T. N.; Snaith, H. J. Efficient hybrid solar cells based on meso-superstructured organometal halide perovskites. Science 2012, 338, 643-647.

(27) Grancini, G.; Roldán-Carmona, C.; Zimmermann, I.; Mosconi, E.; Lee, X.; Martineau, D.; Narbey, S.; Oswald, F.; De Angelis, F.; Graetzel, M.; Nazeeruddin, M. K. One-year stable perovskite solar cells by $2 \mathrm{D} / 3 \mathrm{D}$ interface engineering. Nat. Commun. 2017, 8, No. 15684.

(28) Gao, F.; Zheng, Q.; Zhang, Y. Stability improvement of perovskite solar cells for application of $\mathrm{CuInS}_{2}$ quantum dot-modified $\mathrm{TiO}_{2}$ nanoarrays. ACS Omega 2019, 4, 3432-3438.

(29) Zhang, W.; Li, Y.; Liu, X.; Tang, D.; Li, X.; Yuan, X. Ethyl acetate green antisolvent process for high-performance planar lowtemperature $\mathrm{SnO}_{2}$-based perovskite solar cells made in ambient air. Chem. Eng. J. 2020, 379, No. 122298.

(30) Dai, W. B.; Xu, S.; Zhou, J.; Hu, J.; Huang, K.; Xu, M. Leadfree, stable, and effective double $\mathrm{FA}_{4} \mathrm{Ge}_{\mathrm{II}} \mathrm{Sb}_{\mathrm{III}} \mathrm{Cl}_{12}$ perovskite for photovoltaic applications. Sol. Energy Mater. Sol. Cells 2019, 192, 140-146.

(31) Devi, C.; Mehra, R. Device simulation of lead-free $\mathrm{MASnI}_{3}$ solar cell with $\mathrm{CuSbS}_{2}$ (copper antimony sulfide). J. Mater. Sci. 2019, $54,5615-5624$.

(32) $\mathrm{Fu}, \mathrm{H}$. Review of lead-free halide perovskites as light-absorbers for photovoltaic applications: from materials to solar cells. Sol. Energy Mater. Sol. Cells 2019, 193, 107-132.

(33) Yun, S.; Qin, Y.; Uhl, A. R.; Vlachopoulos, N.; Yin, M.; Li, D.; Han, X.; Hagfeldt, A. New-generation integrated devices based on dye-sensitized and perovskite solar cells. Energy Environ. Sci. 2018, 11, 476-526.

(34) Huan, T. N.; Dalla Corte, D. A.; Lamaison, S.; Karapinar, D.; et al. Low-cost high-efficiency system for solar-driven conversion of $\mathrm{CO}_{2}$ to hydrocarbons. Proc. Natl. Acad. Sci. U.S.A. 2019, 116, 97359740.

(35) Wojciechowski, K.; Forgács, D.; Rivera, T. Industrial opportunities and challenges for perovskite photovoltaic technology. Sol. RRL 2019, 3, No. 1900144.

(36) Siegler, T. D.; Shimpi, T. M.; Sampath, W. S.; Korgel, B. A. Development of wide bandgap perovskites for next-generation lowcost CdTe tandem solar cells. Chem. Eng. Sci. 2019, 199, 388-397.

(37) Choi, I. Y.; Kim, C. U.; Park, W.; Lee, H.; Song, M. H.; Hong, K. K.; Seok, S. I.; Choi, K. J. Two-terminal mechanical perovskite/ silicon tandem solar cells with transparent conductive adhesives. Nano Energy 2019, 65, No. 104044.

(38) Bashir, A.; Shukla, S.; Lew, J. H.; Shukla, S.; Bruno, A.; Gupta, D.; Baikie, T.; Patidar, R.; Akhter, Z.; Priyadarshi, A.; Mathews, N.; Mhaisalkar, S. G. Spinel $\mathrm{Co}_{3} \mathrm{O}_{4}$ nanomaterials for efficient and stable large area carbon-based printed perovskite solar cells. Nanoscale 2018, $10,2341-2350$.

(39) Arora, N.; Dar, M. I.; Hinderhofer, A.; Pellet, N.; Schreiber, F.; Zakeeruddin, S. M.; Grätzel, M. Perovskite solar cells with CuSCN hole extraction layers yield stabilized efficiencies greater than $20 \%$. Science 2017, 358, 768-771.

(40) Xu, X.; Liu, Z.; Zuo, Z.; Zhang, M.; Zhao, Z.; Shen, Y.; Zhou, H.; Chen, Q.; Yang, Y.; Wang, M. Hole selective NiO contact for efficient perovskite solar cells with carbon electrode. Nano Lett. 2015, $15,2402-2408$.

(41) Islam, M. B.; Yanagida, M.; Shirai, Y.; Nabetani, Y.; Miyano, K. $\mathrm{NiO}_{\mathrm{x}}$ hole transport layer for perovskite solar cells with improved stability and reproducibility. ACS Omega 2017, 2, 2291-2299.

(42) Hu, R.; Zhang, R.; Ma, Y.; Liu, W.; Chu, L.; Mao, W.; Zhang, J.; Yang, J.; Pu, Y.; Li, X. Enhanced hole transfer in hole-conductor-free perovskite solar cells via incorporating cus into carbon electrodes. Appl. Surf. Sci. 2018, 462, 840-846.

(43) Haque, M. A.; Sheikh, A. D.; Guan, X.; Wu, T. Metal oxides as efficient charge transporters in perovskite solar cells. Adv. Energy Mater. 2017, 7, No. 1602803.

(44) Nouri, E.; Mohammadi, M. R.; Lianos, P. Construction of perovskite solar cells using inorganic hole-extracting components. ACS Omega 2018, 3, 46-54.

(45) Islam, M. B.; Yanagida, M.; Shirai, Y.; Nabetani, Y.; Miyano, K. $\mathrm{NiO}_{\mathrm{x}}$ Hole transport layer for perovskite solar cells with improved stability and reproducibility. ACS Omega 2017, 2, 2291-2299.

(46) Zhou, L.; Zuo, Y.; Mallick, T. K.; Sundaram, S. Enhanced efficiency of carbon-based mesoscopic perovskite solar cells through a tungsten oxide nanoparticle additive in the carbon electrode. Sci. Rep. 2019, 9, No. 8778.

(47) Granqvist, C. G. Oxide electrochromics: An introduction to devices and materials. Sol. Energy Mater. Sol. Cells 2012, 99, 1-13.

(48) Cannavale, A.; Eperon, G. E.; Cossari, P.; Abate, A.; Snaith, H. J.; Gigli, G. Perovskite photovoltachromic cells for building integration. Energy Environ. Sci. 2015, 8, 1578-1584.

(49) Roy, A.; Ghosh, A.; Bhnadari, S.; Selvaraj, P.; Sundaram, S.; Mallik, T. K. Color comfort evaluation of dye-sensitized solar cell (DSSC) based building-integrated photovoltaic (BIPV) glazing after 2 years of ambient exposure. J. Phys. Chem. C 2019, 123, 23834-23837.

(50) Mei, A.; Li, X.; Liu, L.; Ku, Z.; Liu, T.; Rong, Y.; Xu, M.; Hu, M.; Chen, J.; Yang, Y.; Grätzel, M.; Han, H. A hole-conductor-free, fully printable mesoscopic perovskite solar cell with high stability. Science 2014, 345, 295-298.

(51) Xiong, Y.; Zhu, X.; Mei, A.; Qin, F.; Liu, S.; Zhang, S.; Jiang, Y.; Zhou, Y.; Han, $\mathrm{H}$. Bifunctional $\mathrm{Al}_{2} \mathrm{O}_{3}$ interlayer leads to enhanced open-circuit voltage for hole-conductor-free carbon-based perovskite solar cells. Sol. RRL 2018, 2, No. 1800002.

(52) Senthilarasu, S.; Fernández, E. F.; Almonacid, F.; Mallick, T. K. Effects of spectral coupling on perovskite solar cells under diverse climatic conditions. Sol. Energy Mater. Sol. Cells 2015, 133, 92-98.

(53) Stubhan, T.; Li, N.; Luechinger, N. A.; Halim, S. C.; Matt, G. J.; Brabec, C. J. High fill factor polymer solar cells incorporating a low temperature solution processed $\mathrm{WO}_{3}$ hole extraction layer. $A d v$. Energy Mater. 2012, 2, 1433.

(54) Yi, H.; Wang, D.; Duan, L.; Haque, F.; Xu, C.; Zhang, Y.; Conibeer, G.; Uddin, A. Solution-processed $\mathrm{WO}_{3}$ and water-free PEDOT:PSS composite for hole transport layer in conventional perovskite solar cell. Electrochim. Acta 2019, 319, 349-358.

(55) Vemuri, R. S.; Bharathi, K. K.; Gullapalli, S. K.; Ramana, C. V. Effect of Structure and size on the electrical properties of nanocrystalline $\mathrm{WO}_{3}$ films. ACS Appl. Mater. Interfaces 2010, 2, $2623-2628$.

(56) Gillet, M.; Lemire, C.; Gillet, E.; Aguir, K. The role of surface oxygen vacancies upon $\mathrm{WO}_{3}$ conductivity. Surf. Sci. 2003, 532-535, 519-525.

(57) Granqvist, C. G. Electrochromic tungsten oxide films: review of progress 1993-1998. Sol. Energy Mater. Sol. Cells 2000, 60, 201-262.

(58) Ku, Z.; Rong, Y.; Xu, M.; Liu, T.; Han, H. Full printable processed mesoscopic $\mathrm{CH}_{3} \mathrm{NH}_{3} \mathrm{PbI}_{3} / \mathrm{TiO}_{2}$ heterojunction solar cells with carbon counter electrode. Sci. Rep. 2013, 3, No. 3132.

(59) Chan, C.-Y.; Wang, Y.; Wu, G.-W.; Wei-Guang Diau, E. Solvent-extraction crystal growth for highly efficient carbon-based mesoscopic perovskite solar cells free of hole conductors. J. Mater. Chem. A 2016, 4, 3872-3878.

(60) Liu, S.; Cao, K.; Li, H.; Song, J.; Han, J.; Shen, Y.; Wang, M. Full printable perovskite solar cells based on mesoscopic $\mathrm{TiO}_{2} /$ $\mathrm{Al}_{2} \mathrm{O}_{3} / \mathrm{NiO}$ (carbon nanotubes) architecture. Sol. Energy 2017, 144, $158-165$. 